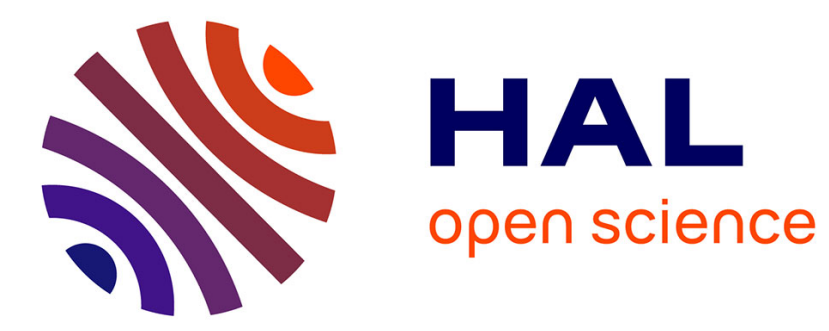

\title{
Expression of the stem cell marker ALDH1 in the normal breast of BRCA1 mutation carriers
}

Marise R. Heerma van Voss, Petra Groep, Joost Bart, Elsken Wall, Paul J. Diest

\section{- To cite this version:}

Marise R. Heerma van Voss, Petra Groep, Joost Bart, Elsken Wall, Paul J. Diest. Expression of the stem cell marker ALDH1 in the normal breast of BRCA1 mutation carriers. Breast Cancer Research and Treatment, 2010, 123 (2), pp.611-612. 10.1007/s10549-010-1005-x . hal-00550605

\section{HAL Id: hal-00550605 https://hal.science/hal-00550605}

Submitted on 29 Dec 2010

HAL is a multi-disciplinary open access archive for the deposit and dissemination of scientific research documents, whether they are published or not. The documents may come from teaching and research institutions in France or abroad, or from public or private research centers.
L'archive ouverte pluridisciplinaire HAL, est destinée au dépôt et à la diffusion de documents scientifiques de niveau recherche, publiés ou non, émanant des établissements d'enseignement et de recherche français ou étrangers, des laboratoires publics ou privés. 
Expression of the stem cell marker ALDH1 in the normal breast of BRCA1 mutation carriers

Marise R Heerma van Voss ${ }^{1}$, Petra van der Groep ${ }^{2}$, Joost Bart ${ }^{3}$, Elsken van der Wall $^{2}$, Paul J van Diest ${ }^{1}$.

${ }^{1}$ Department of Pathology, University Medical Center Utrecht, ${ }^{2}$ Department of Internal Medicine, University Medical Center Utrecht, and ${ }^{3}$ Department of Pathology, University Medical Center Groningen, The Netherlands

Address for correspondence:

Prof. P.J. van Diest, MD, PhD

Head, Department of Pathology

University Medical Centre Utrecht

PO Box 85500

3508 GA Utrecht

The Netherlands

Email p.j.vandiest@umcutrecht.nl

Tel: (31) 887556565

Fax: (31) 302544990

Keywords BRCA1, ALDH1, stem cells, normal breast 
To the editor,

The BRCA1 protein makes mammary stem cells differentiate into mature luminal and myoepithelial cells [1-4]. If a BRCA1 mutation results in a differentiation block, an enlarged stem cell component might be present in the benign tissue of BRCA1 mutation carriers, and these mammary stem cells could be the origin of BRCA1 related breast cancer. Several markers have been identified for the selection of human (cancer) stem cells, of which Aldehyde dehydrogenase 1 (ALDH1) is among the most widely studied ones. ALDH1 is a cytosolic detoxifying enzyme responsible for the oxidation of (retin)aldehydes into retinoids [1], which has been put forward as a marker of both normal human mammary stem cells and breast cancer stem cells. The exact function of ALDH1 in (mammary) stem cells remains largely unknown, but it is thought to play a role in cellular differentiation, mainly through the retinoid signaling pathway [1]. Knockdown of BRCA1 in primary breast epithelial cells leads to accumulation of cells expressing ALDH1 and a decrease in ER positive cells expressing luminal epithelial markers. Furthermore, in the normal tissue of BRCA1 mutation carriers, clusters of ALDH1 positive cells have been described that were ER negative and showed loss of heterozygosity (LOH) of BRCA1. These results indicate that BRCA1 might indeed serve as a stem cell regulator in the mammary epithelium and that the stem cell pool in the normal tissue of BRCA1 mutation carriers might be enlarged [5]. We therefore compared ALDH1 expression in normal breast tissue of prophylactic mastectomies of 32 BRCA1 mutation carriers to 32 age-matched mammoplasty controls. Immunohistochemistry for ALDH1 (clone 44/ALDH, BD Transduction Laboratories, 1:100, $60 \mathrm{~min}$ ) and ER $\alpha$ (1D5, Dako, 1:80, $60 \mathrm{~min})$ was done after antigen retrieval of paraffin sections. Scoring was done by two observers (MRHvV, PJvD) blinded to BRCA1 mutation status. The number of clusters (> 3 adjacent cells) of ALDH1 positive cells was counted per section and the 
amount of cells per cluster was estimated, excluding all areas with histologic aberrations such as hyperplastic lesions, columnar cell lesions, apocrine metaplasia and ductectasia. The intensity of stromal expression was scored from 0-4. The number of ER $\alpha$ positive cells was estimated.

Comparing BRCA1 carriers and non-carriers (table), there were no differences in presence or size of clusters of ALDH1 positive epithelial cells. This contradicts previous results from Liu et al., who reported clusters of ALDH1 positive to be solely present in $38 \%$ of the prophylactic mastectomy tissue $(n=13)$ of mutation carriers and not in 22 sporadic controls [5]. This may be caused by their much smaller non-age matched population. Another recent study also reported ALDH1 positive clusters in mammoplasties of non-carriers [1] and Burga et al. reported a similar ALDH1 population (4.5-6\%) in colonies grown out of human mammary epithelial cells derived from prophylactic mastectomies and mammoplasties [1]. Interestingly, a significantly higher stromal expression was observed in the benign tissue of BRCA1 mutation carriers in the present study, especially in the intralobular stroma (figure). The mean percentage of ER positive cells was slightly but not significantly lower in the group of carriers (38.0\%) than in non-carriers $(43.4 \%)(\mathrm{P}=0.42)$.

In conclusion, an enlarged mammary epithelial stem cell component in the benign tissue of BRCA1 mutation carriers could not be detected, although the benign stroma of BRCA1 mutation carriers shows higher ALDH1 expression than age-matched controls. This implies that BRCA1 may be an (in)direct regulator of mammary stromal ALDH1 expression. 


\section{References}

1 Chen S, Parmigiani G (2007). Meta-analysis of BRCA1 and BRCA2 penetrance. J Clin Oncol 25:1329-1333.

2 Honrado E, Benitez J, Palacios J (2006). Histopathology of BRCA1- and BRCA2-associated breast cancer. Crit Rev Oncol Hematol 59:27-39.

3 Bane AL, Beck JC, Bleiweiss I, Buys SS, Catalano E, Daly MB et al (2007). BRCA2 mutation-associated breast cancers exhibit a distinguishing phenotype based on morphology and molecular profiles from tissue microarrays. Am J Surg Pathol 31:121-128.

4 Van der Groep P, Bouter A, van der ZR, Siccama I, Menko FH, Gille JJ et al (2006). Distinction between hereditary and sporadic breast cancer on the basis of clinicopathological data. J Clin Pathol 59:611-617.

5 Liu S, Ginestier C, Charafe-Jauffret E, Foco H, Kleer CG, Merajver SD et al (2008). BRCA1 regulates human mammary stem/progenitor cell fate. Proc Natl Acad Sci USA 105:1680-1685.

Table. ALDH1 expression in the benign breast tissue of BRCA1 mutation carriers and non-carriers.

\begin{tabular}{lcccccc} 
& $\begin{array}{c}\text { non-carriers } \\
(\mathrm{n}=32)\end{array}$ & $\begin{array}{c}\text { BRCA1 } \\
\text { mutation } \\
\text { carriers }(\mathrm{n}=32)\end{array}$ \\
\hline \hline & $\mathrm{N}$ & Percentage & $\mathrm{N}$ & Percentage value \\
\hline $\begin{array}{l}\text { Clusters } \\
\text { of }\end{array}$ & Present & 27 & $84.4 \%$ & 22 & $68.8 \%$ & 0.14 \\
\hline
\end{tabular}

ALDH1

positive

\begin{tabular}{llccccc} 
cells & Absent & 5 & $15.6 \%$ & 10 & $31.3 \%$ & \\
\hline Stromal & Absent & 6 & $19 \%$ & 7 & $22 \%$ & 0.02 \\
ALDH1 & Weak & 11 & $34 \%$ & 3 & $9 \%$ & \\
expression & Moderate & 11 & $34 \%$ & 9 & $28 \%$ & \\
& Strong & 4 & $13 \%$ & 13 & $41 \%$ & \\
\hline
\end{tabular}

$\mathrm{N}$

$\mathrm{N}$ 


\begin{tabular}{lccc}
\hline $\begin{array}{l}\text { Number of ALDH1 } \\
\text { clusters }\end{array}$ & 6.9 & 9.6 & 0.24 \\
\cline { 1 - 1 } $\begin{array}{l}\text { Mean number of } \\
\text { cells per ALDH1 } \\
\text { cluster }\end{array}$ & & & \\
\hline
\end{tabular}




\section{Figure}
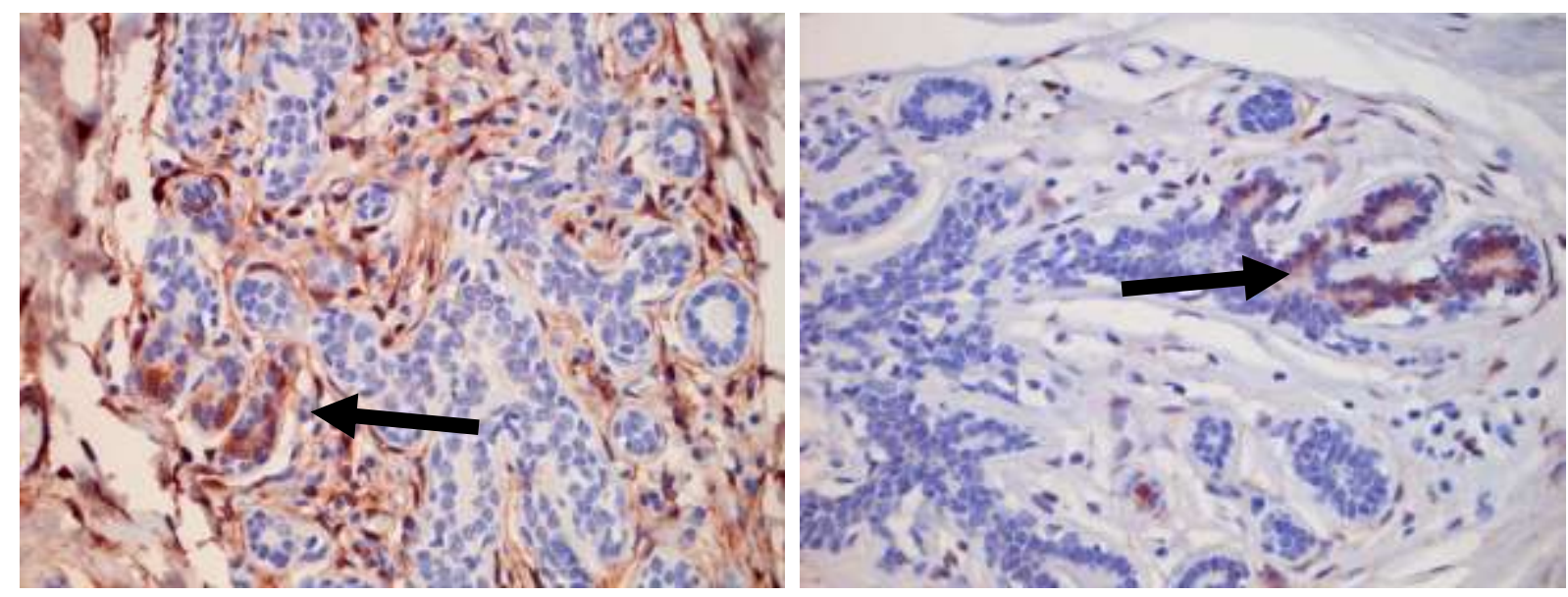

Expression of ALDH in normal and malignant breast tissues. Left: Normal breast tissue of a BRCA1 mutated patients showing clusters of ALDH1 positive epithelial cells (arrow) and strong expression in the intralobular stroma. Right: Normal breast tissue of a sporadic patients showing clusters of ALDH1 positive epithelial cells (arrow) but hardly expression in the intralobular stroma. 